\title{
Street-level workers, managers and institutional tensions: a comparative ethnography of healthcare practices of in/ exclusion in three Italian public organisations
}

\author{
Roberta Perna(i)
}

\section{Correspondence: roberta.perna@ csic.es \\ Consejo Superior de Investigaciones Científicas - Instituto de Políticas y Bienes Públicos (CSIC-IPP), Calle de Albasanz 26-28, 28037 Madrid, Spain}

\begin{abstract}
Public organisations are fundamental actors in migrant incorporation processes, as they are in charge of assessing migrants' entitlement and providing access to welfare services. While a lot has been written on the individual determinants of street-level decisions, the role of organisational and institutional factors in shaping implementation practices has received little attention so far. By linking the streetlevel bureaucracy approach and the neo-institutionalist perspective in organisational analysis, this article investigates how public organisations mediate migrant incorporation processes in the field of healthcare. Drawing on a comparative ethnographic study of three public health organisations in an Italian region, the paper suggests that, in times of institutional tensions, managers' priorities and framings of the issue, the ways they respond to decision-makers' goals and allocate resources for implementing them, orient - and lead to variation in - street-level healthcare practices of in/exclusion for migrants with irregular status.
\end{abstract}

Keywords: Healthcare in/exclusion, Institutional tensions, Organisations, High-level managers, Street-level bureaucracy, Italy

\section{Introduction}

Over the past decade, there have been significant advances in the field of migrant incorporation studies in Europe, focusing on both the macro-level of migration and integration policies and the micro-level of migrants' individual trajectories and agency (Zincone et al. 2011), as well as on the role played by different institutional and noninstitutional actors in the multi-level governance of migrant incorporation policymaking (Garcés-Mascareñas and Penninx 2016).

In the realm of social rights, in particular, public organisations are of utmost importance, as they are in charge of assessing migrants' welfare entitlements and providing access to social protection (Chauvin and Garcés-Mascareñas 2014). While formal

(c) The Author(s). 2021 Open Access This article is licensed under a Creative Commons Attribution 4.0 International License, which permits use, sharing, adaptation, distribution and reproduction in any medium or format, as long as you give appropriate credit to the original author(s) and the source, provide a link to the Creative Commons licence, and indicate if changes were made. The images or other third party material in this article are included in the article's Creative Commons licence, unless indicated otherwise in a credit line to the material. If material is not included in the article's Creative Commons licence and your intended use is not permitted by statutory regulation or exceeds the permitted use, you will need to obtain permission directly from the copyright holder. To view a copy of this licence, visit http://creativecommons.org/licenses/by/4.0/. 
policies define the degree of eligibility to social rights of different migrant categories, the responsibility of concretely drawing the line between those who will concretely access social services and those who will not is in the hands of street-level organisations operating on the front-line of welfare states (Brodkin 2011a). In doing so, these actors may not share and conform to governments' orientations and interests (Boswell 2007). Rather, they may adapt, bend and even subvert official policy frameworks to pursue their interests and priorities. Therefore, investigating how public organisations act as policy intermediaries opens up important questions about their role in migrant incorporation processes, addressing them not just as policy implementers, but also as de facto policymakers. Accordingly, welfare services are particularly suited to observe mechanisms of in/exclusion, as these are the places where decisions about who belongs to a given community and who will have access to limited public resources are made (Thelen et al. 2014).

Drawing on a comparative ethnographic study of three public health organisations in the Northern Italian region of Piemonte, this article analyses how organisations mediate healthcare incorporation processes of migrants with irregular status (hereafter: [MIS]), paying particular attention to the role played by organisations' managers in orienting street-level workers' practices. By linking the street-level bureaucracy literature (Hupe 2019) with the neo-institutionalist perspective in organisational analysis (Peters 2019), it suggests that the interplay of institutional and organisational factors matters in orienting street-level decisions. The layering of different - and sometimes conflictive goals over time and the consequent tensions in the institutional context, and the different ways public health organisations' managers interpret and respond to them, lead to variation in the practices and decisions adopted by street-level workers in their encounters with MIS, ultimately determining migrants' inclusion into - or exclusion from - public healthcare services.

The article is structured as follows. After presenting the theoretical framework of the research, it describes the Italian policy regulating the access to healthcare for MIS and the research strategy. Then, it reconstructs the healthcare field in Piemonte, paying attention to its actors' relations, as well as to the changing framing of the policy issue over time. Finally, the article discusses the practices carried out by street-level workers at three public health organisations, suggesting that differences in high-level managers' priorities and framings of the same policy issue, the ways they responded to decisionmakers' goals over time and allocated resources for implementing them, oriented street-level workers' practices towards MIS, leading to significant variation in policy implementation practices in the field.

\section{Theoretical framework}

Street-level bureaucrats can be defined as public service workers who directly interact with clients in the course of their daily jobs, granting access to and providing services within governmental programs (Lipsky 1980[2010], p. 3). In carrying out their daily job, these actors are faced with structural constraints, i.e. inadequate resources, increasing demands, ambiguous policy goals, and complex evaluations of users' claims. To get the job done while coping with these constraints, street-level bureaucrats adopt different discretionary strategies, which indirectly but significantly shape policy on the ground. 
Since Lipsky's seminal work, a range of empirical studies have analysed the individual determinants of street-level discretion, including workers' policy predispositions, gender, race, and degree of professionalisation (for a comprehensive review, see: Hupe 2019; Maynard-Moody and Portillo 2010). In the field of healthcare, in particular, professional values and autonomy have been considered as fundamental drivers of discretionary practices. According to Evans (2011, p. 371), professional status influences the extent of freedom that an occupational group exercises and entails a commitment to values that should orient the use of discretion. Hence, when health workers face tasks that contrast with their ethical codes, discretion often becomes an expression of a professional culture that guides individual practices (Ellis 2011).

From this perspective, research on the migration-healthcare nexus often portrays health workers as actors who seek to open formal and informal healthcare trajectories for MIS (van der Leun 2006; Fernández-Kelly 2012). Scholars argue, for instance, that, thanks to "a deep rooting of humanism in the minds of pragmatic health professionals" (Dauvrin et al. 2012, p. 6), "committed providers" (Marrow 2012, p. 852) often modify and even bend restrictive entitlement criteria, adopting "benevolent contra legem practices" (Zincone 1998, p. 45) to guarantee healthcare access for migrants, and MIS in particular.

Hence, street-level workers are not passive actors in charge of implementing governmental policies. They can create and exploit policy loopholes to grant healthcare access for vulnerable migrants. At the same time, however, discretionary decisions do not come out of the blue. Rather, they are embedded into the wider organisational and institutional context (Lipsky 1980[2010]; Thelen et al. 2014). It is therefore important to adopt a multifocal approach that allows grasping the interconnections that exist between the micro-level of bureaucrats' practices, the meso-level of the public organisation, and the macro-level of the wider institutional context.

At the meso level, the organisations' management plays an important role in orienting street-level practices (Riccucci et al. 2004; Ellis 2011; Evans 2011; Brodkin 2012). Managers of public organisations interpret legal rules in regard to organisations' priorities, define workers' positions within the organisation, organise, coordinate and distribute work, and hold prerogatives to reward or penalise staff using formal and informal incentives or sanctions. As Evans (2011, p. 383) argues, however, "'management' is a complex, internally differentiated group": from her perspective, line managers often identify themselves more with the idea and commitments of professional social work than with high-level managers' concerns of constraining spending. Therefore, by effectively choosing "what counts" in an organisation (Brodkin 2011a, p. i255), these actors hold significant power in orienting street-level work towards different courses of action.

At the macro level, practices are shaped by the institutional logics that operate in a field. Institutions give meaning and direction to - and thereby also restrict - the patterns of practices that are assumed to be appropriate, legitimate, or even permitted for organisations operating in a field (Powell and DiMaggio 1991; Peters 2019). Therefore, policy implementation practices are embedded in a broad meaning system - the institutional logic - that defines the "interests, identities, values, and assumptions of individuals and organisations" (Thornton and Ocasio 2008, p. 103). Street-level workers are exposed to these logics through their membership in organisations that are part of a 
given organizational field (Garrow and Grusky 2013), which can be defined as "those organisations that, in the aggregate, constitute a recognised area of institutional life: key suppliers, resource and product consumers, regulatory agencies, and other organisations that produce similar services or products" (DiMaggio and Powell 1983, p. 148).

Yet, institutions exist in nested systems that cut across and connect different levels and policy domains (Lawrence and Suddaby 2006, p. 248). In the field of healthcare and migration, for instance, Portes et al. (2009) identify different coping strategies adopted by health organisations towards MIS in the US ("escapists", "profit-seekers", "angels" and "good Samaritans"). According to the authors, these strategies result from the ways these organisations reconciled with two conflicting definitions of healthcare in the US: as a scarce good to be purchased or sold in the market, or as a human right to be rendered accessible to all. From this perspective, street-level discretionary practices can be interpreted as responses to double-bind situations (Bierschenk 2014, pp. 239240), which may originate from the "layering" of new norms on top of or alongside pre-existing ones (Mahoney and Thelen 2010, pp. 16-17), as well as from the "conversion" of existing institutions to new goals, functions, or purposes (17-18).

Finally, while institutions orient organisations' actions "from above", actors also participate in disrupting institutions (Lawrence and Suddaby 2006), re-defining the meaning of taken-for-granted practices and norms "from below" (Rice 2012). This may take place via two mechanisms. Indirectly, organisations may ceremonially comply with institutionalised norms and practices to guarantee their legitimacy in a given field, but build gaps between formal structures and actual practices in their daily activities ((Meyer and Rowan (1977)'s "decoupling strategy"). Directly, actors may overtly challenge taken-for-granted practices, undermining the regulative and normative mechanisms that lead field members to comply with institutions (Lawrence and Suddaby 2006, pp. 234-238). This is particularly likely to happen at times of "legitimacy shortfalls" (Alink et al. 2001, p. 286), that is, "when established policy frames, organisational structures and modes of policymaking and service delivery are being fundamentally criticised by political actors within and outside the sector". In that case, organisational actors can become "less likely to take [institutional arrangements] for granted and more likely to question, and possibly diverge from, them" (Battilana et al. 2009, p. 75). As Mahoney and Thelen (2010, p. 14) argue, it is "in the 'gaps' or 'soft spots' between the rule and its interpretation [... that] contests over - and at the same time within - institutions take place".

By connecting these analytical perspectives, this article moves beyond the analysis of individual-level factors to explain variation in street-level practices towards MIS. It aims at providing a deeper understanding of the ways in which institutional and organisational factors interplay and orient street-level practices, which shape the inclusion of MIS into - or their exclusion from - public healthcare.

\section{Inclusive healthcare entitlements in an increasingly hostile environment}

Healthcare access for MIS was a neglected issue in the Italian migration debate throughout the 1970s and 1980s. Except for emergency care, MIS were formally excluded from the country's healthcare system (Sistema Sanitario Nazionale [SSN]). At the turn of the 1990s, however, migration inflows consistently increased to Italy, setting the agenda for a comprehensive reform of the country's immigration framework. It is 
in that window of opportunity that the issue of MIS' healthcare gained momentum, when humanitarian organisations, professional associations and individual workers committed with MIS' health created a national professional network (Società Italiana di Medicina delle Migrazioni [SIMM]) and advocated for the adoption of an inclusive policy regulating MIS' healthcare access (Geraci and Bodini 2011).

As a result of this bottom-up mobilisation, which combined the "construction of a normative network" with "advocacy" ((Lawrence and Suddaby (2006)'s practices of "creating institutions"), members of the new-born SIMM participated in the drafting of what was to become the current health section of the 1998 Immigration Law, according to which MIS "shall be guaranteed access to urgent and essential care". ${ }^{1}$ In procedural terms, healthcare is provided after the person applies for and receives an anonymous code, which is valid for 6 months and can be renewed. According to the law, registration can also be carried out if the person has no identity documents, and health workers cannot report MIS to the police when they require healthcare. In terms of funding, treatments provided to MIS are reimbursed to regions by the central government, while the organisation and provision of primary health services (including intercultural mediation activities, human and physical resources allocated to dedicated clinics) lie on each region's budget. On the side of MIS, they should participate in the costs of treatments received. However, as in the case of Italian citizens, they may be exempted from co-payments for health reasons (eg, in case of chronic diseases or severe pathologies) or economic reasons (by signing a self-certification of their status of economic indigence).

Although showing a high level of inclusiveness, the Italian policy regulating healthcare access for MIS has been increasingly surrounded by several ambiguities due to its blurred boundaries, nested between immigration and healthcare policies - and their different logics and goals. Accordingly, immigration policy reforms adopted in the last 20 years (the so-called 2002 Bossi-Fini Law, the 2009 Security Package, and the 2018 Immigration and Security Decrees) have been strongly oriented towards an "order and control" frame, leading to the criminalisation of irregular migration and introducing several "pathogenic elements" affecting migrants' physical, psychological and mental health status (Geraci and Bodini 2011).

Moreover, after the outbreak of the 2008 recession, central governments have strengthened austerity measures to reduce Italy's high public debt, significantly cutting public healthcare expenditure (de Belvis et al. 2012). Among the measures introduced, a more rigid selection of healthcare beneficiaries has been presented as a key tool to reduce misuse and abuse of the SSN, particularly from "medical tourists", i.e., people who supposedly migrate to Italy to take advantage of its universalistic healthcare system (Pasini and Merotta 2016).

Therefore, the adding of amendments and new goals on top of the existing provision regulating MIS' healthcare access has contributed to create a tension in the wider institutional environment. A control-oriented logic, which targets irregular migration and "undeserving" beneficiaries of public resources, has come to coexist with the preexisting medical-humanitarian logic, which supports healthcare provisions for

${ }^{1}$ Urgent care refers to services that cannot be deferred without putting the person's life at risk. Essential care includes diagnostic and therapeutic services related to pathologies that are non-dangerous in the short term, but could cause greater damage to the person's health over time (e.g. complications, chronic conditions). 
vulnerable migrants, as invoked by professional healthcare networks and stated in the health section of the 1998 Law.

\section{Empirical case and methods}

\section{Case selection}

As mentioned before, the 1998 Law regulates MIS' healthcare entitlements nationally, while each region holds the responsibility of identifying the most appropriate tools to guarantee healthcare access within its regional healthcare system.

Among the 20 Italian regions, Piemonte was selected as representative case in terms of immigration and healthcare dynamics, as well as in terms of policy responses to MIS' health needs. Firstly, it is characterised by a sizeable and growing foreign population, in line with national trends (9.6\% of foreigners residing in the region in 2016, compared with $8.3 \%$ at the national level). ${ }^{2}$ Secondly, like in the majority of Italian regions, Piemonte healthcare system has been targeted by significant austerity measures following the 2008 recession pursuing the "rationalization of health expenditure" and "cost control" (Ministry of Health, Ministry of Economy and Finance, Piemonte Region, 29 July 2010), to be achieved - among other measures - via "the reduction in health prescriptions" and "the responsibilisation of health workers" (Piemonte Region, Law no.3/2012), the latter being identified as cost-drivers in the system.

Finally, although regions have adopted different measures to transpose the health section of the 1998 Law, 13 of them, including Piemonte, have created targeted clinics as a specific service provided by the public health organisations (Olivani and Panizzut 2019). Piemonte provides healthcare to MIS through 13 clinics where trained administrative workers, health professionals and intercultural mediators have to, first, assess MIS's entitlement to healthcare and, then, provide primary care to them (Regional law no. 20-9847 of 20/10/2008). Regional funding is allocated to each organisation for the daily functioning of the clinic (a fixed sum) and according to the number of MIS treated (on a reimbursement basis), while organisations may decide to allocate additional resources to the service via their general budget.

After an exploratory study, three clinics were purposefully sampled for the comparative purpose of the study to provide variation in the structural constraints identified by the street-level bureaucracy literature to explain street-level discretionary strategies (Brodkin 2012), namely the number of MIS applying for healthcare (higher than/equal to/lower than regional average) and the organisational resources allocated by the management to the functioning of the service (more than/equal to/less than the minimum threshold set by the regional law). The final sample includes the cases summarised in Table 1, which are contrasted with the minimum requirements set by the 2008 regional law.

\section{Methods}

Data were collected between 2014 and 2017 through document analysis, semistructured interviews, and observation of the daily encounters between health workers and MIS at the sampled clinics. In order to reconstruct the transformation of the field

${ }^{2}$ As estimates concerning the presence of MIS in Piemonte are not available, data refers to the foreign resident population. 
Table 1 Minimum regional requirements and sampled clinics

\begin{tabular}{|c|c|c|c|c|}
\hline & $\begin{array}{l}2008 \text { regional law (minimum } \\
\text { requirements) }\end{array}$ & Clinic-N & Clinic-C & Clinic-S \\
\hline $\begin{array}{l}\text { Location and } \\
\text { average } \\
\text { number of } \\
\text { MIS per year) }\end{array}$ & $/ / /$ & $\begin{array}{l}\text { North } \\
\text { (industrial area); } \\
=\text { regional } \\
\text { average (2000/ } \\
\text { year) }\end{array}$ & $\begin{array}{l}\text { Centre } \\
\text { (metropolitan area); } \\
>\text { regional average } \\
(11,000 / \text { year })\end{array}$ & $\begin{array}{l}\text { South (agricultural } \\
\text { area); } \\
<\text { regional average } \\
\text { (800/year) }\end{array}$ \\
\hline \multicolumn{5}{|c|}{ Organisational resources } \\
\hline - Human & $\begin{array}{l}1 \text { line manager } \\
1 \text { doctor per day } \\
2 \text { nurses per day } \\
1 \text { dedicated admin. Worker per } \\
\text { day } \\
\text { intercultural mediators (no. } \\
\text { depending on need) }\end{array}$ & $\begin{array}{l}1 \text { line manager } \\
3 \text { doctors } \\
6 \text { nurses } \\
1 \text { dedicated } \\
\text { admin. Worker } \\
1 \text { intercultural } \\
\text { mediator (+ } 2 \\
\text { available on } \\
\text { demand) }\end{array}$ & $\begin{array}{l}1 \text { line manager } \\
2 \text { doctors } \\
2 \text { nurses } \\
4 \text { intercultural } \\
\text { mediators also in } \\
\text { charge of } \\
\text { registration } \\
\text { procedure }\end{array}$ & $\begin{array}{l}1 \text { admin. Line } \\
\text { manager } \\
8 \text { doctors } \\
1 \text { nurse } \\
3 \text { non-dedicated } \\
\text { admin. Workers } \\
\text { no intercultural } \\
\text { mediators }\end{array}$ \\
\hline - Physical & $\begin{array}{l}\text { i. opening hours: } \\
6 \text { h/week (min. } 2 \text { days/week) } \\
\text { ii. physical settings: } \\
\text { dedicated reception desk and } \\
\text { medical room (appropriate } \\
\text { setting to guarantee } \\
\text { confidentiality on health/legal } \\
\text { status of the person) }\end{array}$ & $\begin{array}{l}\text { i. opening hours: } \\
6 \text { h/week } \\
\text { (3 days/week) } \\
\text { ii. physical } \\
\text { settings: } \\
\text { dedicated } \\
\text { reception desk } \\
\text { and medical } \\
\text { room }\end{array}$ & $\begin{array}{l}\text { i. opening hours: } \\
35 \text { h/week } \\
\text { ( } 5 \text { days/week) } \\
\text { ii. physical settings: } \\
\text { dedicated reception } \\
\text { desk and medical } \\
\text { room }\end{array}$ & $\begin{array}{l}\text { i. opening hours: } \\
\text { registration desk: } \\
40 \text { h/week (5 days/ } \\
\text { week) } \\
\text { medical room: } \\
3 \text { h/week } \\
\text { (5 days/week) } \\
\text { ii. physical settings: } \\
\text { Non-dedicated } \\
\text { registration desk } \\
\text { and dedicated } \\
\text { medical room }\end{array}$ \\
\hline
\end{tabular}

over time and identify its cultural repertoires, documents analysed included immigration and healthcare texts adopted between 1980 and 2017, regional guidelines, minutes of the meetings of the regional Clinics' Coordinating Group [CCG] (see below) held in the period 2014-2017, as well as documents produced by SIMM and its regional branch in Piemonte since 1990.

Moreover, 31 semi-structured interviews were conducted with public health organisations' managers, clinics' line managers and street-level personnel working at the three sampled clinics, addressing participants' standard practices in their encounters with MIS and the decisions they adopted when dealing with complex cases due to MIS' health and/or legal status. In addition, ten face-to-face, semistructured interviews were conducted with key informants (regional policymakers, CCG members, representatives of SIMM regional branch, non-governmental organisations concerned with MIS' health) to reconstruct the field in Piemonte and its actors' relations.

Finally, data about street-level decisions were collected through a three-month period of observation at each sampled clinic. Observation was conducted primarily at the clinics' registration desks, due to the sensitive nature of the issue under analysis, thus involving mainly administrative workers and intercultural mediators. Nevertheless, as it was common for doctors and nurses to take part in the intake procedure or discuss specific cases at the registration desks, it became possible to "observe" their daily practices.

Based on verbatim interview transcripts and field notes, a thematic analysis was conducted to compare and contrast participants' narratives and practices in relation to 
common themes and events, and to the clinic they worked at. To guarantee anonymity, participants' names have been omitted and all information allowing for their identification removed.

\section{The healthcare field in Piemonte: from pragmatic innovation to institutional crisis}

Piemonte was one of the first regions that transposed the 1998 Law by creating dedicated health clinics for MIS at the public health organisations of its regional healthcare system. This region's response to the national law, however, was mediated, and even activated, by bottom-up pressures coming from health providers who - at the time of legislative vacuum - provided informal treatments to MIS while pressing for a formal policy definition (Zincone 1998).

In 1996, the region launched a pilot project creating six dedicated clinics in a corresponding number of public health organisations across the region (including Clinic- $\mathrm{N}$ and Clinic-C). This project resulted from the indications provided by an ad hoc Working Group, which wascreated to map existing experiences and propose appropriate solutions to MIS' healthcare, composed by representatives of the region, public hospitals and local health organisations, academics and civil society organisations. Linking a humanitarian discourse with the principles of medical professionalism (Ticktin 2006), this model represented for the clinics' proponents "the best institutional arrangement to provide certainty and continuity of public healthcare for MIS" (interview, CCG-2) and to "assist vulnerable migrants in need" (interview, Region-1) when compared to other policy options, such as providing healthcare through mainstream services or by signing agreements with NGOs (interview, CCG-1).

Therefore, a common model and framing of the issue were progressively delineated at the regional level. In the official documents this group produced over time, some keywords and themes appear repeatedly: healthcare as a "fundamental and enforceable right of the person"; health workers' responsibility "to promote migrants' inclusion into the healthcare system"; the representation of migrants as a "vulnerable category" for whom "targeted interventions" should be developed; and the need for "cultural accommodation in healthcare" (Regional healthcare plans, 1997-1999; 2007-2010; 20122015).

Assumed by regional decision-makers, the 1996 pilot project was re-introduced topdown into the whole region as a model, leading to the consolidation of specific healthcare practices. In 2004, the clinics were officially defined as a "constitutive and structural service of Piemonte healthcare system" (Regional law no. 43-14,393 of 20/ $12 / 2004)$. The ad hoc Working Group was transformed into the CCG, composed by regional officials and the clinic line managers, which promoted a progressive extension of MIS' entitlements and organised training activities on migrants' health for field actors (interview, CCG-1). Consequently, five additional public health organisations of the regional system opened a clinic in line with regional rules. Two others that until then had opposed the model, not agreeing with its aims and procedures, were forced to institutional conformity, as it happened in the case of Clinic-S (interview, Region-1; interview, CCG-2). By 2008 all 13 public health organisations of Piemonte healthcare system had a dedicated clinic for MIS' healthcare in their territory, partly substantially, partly only "ceremonially" (Meyer and Rowan 1977) conforming to the regional model. 
In the late 2000s, however, the 2008 recession and "medical tourism" narratives entered the field, destabilising common framings and practices. Discussions within the CCG increasingly focused on the distinction between "the right to healthcare" and "the right to free-of-charge healthcare", and between "health indigence" and "freeloading" (minutes of CCG meetings, years 2014/2016), giving shape to a polarisation between those who claimed for "their duty to provide healthcare as doctors" and those who affirmed the need to "secure the public healthcare system from abuses" (fieldnotes, CCG meeting, June 2015).

In particular, concerns about "medical tourism" - in a context of limited resources due to state-imposed austerity measures - represented a powerful argument to legitimate stringent controls on MIS' healthcare access. As clearly summarised by a CCG member,

At the beginning it was easy. The 1998 Law was really extensive in terms of entitlement and coverage. Then ... what happened? On the one hand, we have been progressively overcome by indications coming from the Ministry of Health, the Home Ministry, the Ministry of Economy, and Region [ ... ] So, who wins? On the other hand, the EU-enlargement process, which made the phenomenon of medical tourism easier, the Bossi-Fini Law, the fiscal deficit of the SSN and of Piemonte's system, which is currently subject to a debt rescheduling plan, and now the economic crisis and the contextual arrival of thousands of refugees ... well, because of all these events, we have become ... I have to say it, we have become more restrictive in our daily approach to migrants, although the general rules have almost remained the same ... from health providers we are turning into cops (interview, CCG-3).

Replicating the tensions characterising the wider societal environment, and at the same time participating in their production, field actors operated between two coexisting yet conflicting frames resulting from the "layering" of new rules on top of the 1998 Law: a medical-humanitarian frame, grounded on health workers' ethical and professional responsibility towards vulnerable migrants, and a control-oriented frame, legitimated by the need to protect the regional healthcare system from "undeserving freeloaders".

These tensions weakened the legitimacy of CCG's decisions and of the regional policy model more generally, opening up a "legitimacy shortfall" (Alink et al. 2001), with important effects on street-level practices, which differed in the three cases. At Clinic-N, managers continued complying with and defending the established regional approach. The others increasingly challenged the regional model, its common framings and policy tools (Clinic-C) and even openly contrasted it (Clinic-S), reinterpreting and enacting existing rules to pursue stricter gatekeeping goals (Mahoney and Thelen 2010, p. 18). The following section presents these developments.

\section{Healthcare practices on the front-line: managers' positioning and street-level discretion}

Clinic-N: substantial conformity and organisational practices of healthcare inclusion

Created during the 1996 pilot project, MIS's healthcare demands at Clinic-N have remained more or less constant over time, amounting to around $10 \%$ of the total 
demands in the region. Yet, the organisation's management had allocated additional resources to the service since its creation, increasing the number of health workers and extending the opening time of the clinic. Complying substantially with the regional model of MIS' healthcare and the regional guidelines, the organisation's management described the clinic as "a well-functioning and consolidated service" and "the most pragmatic way to take care of a person in a context of uncertainty" (interview, highlevel manager, Clinic-N).

Similarly, Clinic-N's line manager had continuously and actively participated in the CCG and took the side of its defenders when it became increasingly questioned. He described it as a unique place to pragmatically and collectively solve complex cases and to share "a common interpretation of the law from an inclusive perspective" (interview, line-manager, Clinic-N). Likewise, since the opening of Clinic-N, the line manager had organised monthly training activities on administrative and cultural issues related to MIS' health for all workers regardless of their profession, with the aim to "create a common modus operandi" (fieldnotes, line-manager, Clinic-N).

Working in a supportive organisational environment towards MIS' healthcare in general and the clinic's mission in particular, street-level workers usually referred to MIS in terms of "vulnerable patients", that is, sick people with precarious status due to Italy's restrictive immigration policies, and who should be treated unconditionally when in need: "those who come here are in real pain; they really need to have that treatment or medication. Otherwise, they would not come, I can assure you of that. They truly need it" (interview, intercultural mediator, Clinic-N).

Dealing with "patients", the health status of the person was the central concern of these workers, in relation to which daily practices should be defined and performed. As the administrative worker explained to me while managing paperwork, "We are not policemen. Of course we must be careful, but it is not our task to scan documents. We are responsible for people's health; we have to respond to their health needs". Similarly, a doctor explained to me:

We always try to act with prudence. In the immediate moment, we evaluate the person's health status and needs. If that need is urgent, we usually provide the treatment and issue a code with a very short validity, to have time to come to a [n administrative] decision while guaranteeing the person's health. In case the need is not urgent, we do not issue the code but we take our time to study the situation and find the most appropriate solution for the person and the organisation, too (interview, doctor-3, Clinic-N).

Mobilising this medical-humanitarian frame, street-level workers at Clinic-N interpreted their role in terms of public workers who are individually and professionally committed to care for someone in need, who must respond adequately to patients' specific health demands. As a result of that, the worse the health status of the person was, the more these workers actively engaged in taking care of patients and used their room for manoeuvre to open in/formal healthcare trajectories for MIS.

They provided e.g. free samples of medicines or decided to allow MIS who could not be registered into the system to be still examined by a doctor. Hence, these discretionary practices required workers to assume an "affordable" individual responsibility for 
their decision. However, the higher the cost of treatments needed, the less discretionary decisions could be put into practice on an individual basis. In these cases, collective discretionary decisions were taken, assuming the form of organisational strategies of inclusion. Being confronted with a sick person in need of expensive treatments, these workers collectively engaged in order to scale the problem up to the organisation's high-level manager, trying to open alternative healthcare trajectories legitimated by and under the economic responsibility of the public health organisation. Only when this strategy was unsuccessful or impossible to carry out, street-level workers directed the patient to non-profit organisations or private health professionals who could care for persons excluded from the public healthcare system. ${ }^{3}$

\section{Clinic-C: changing managerial priorities and organisational practices of healthcare exclusion}

Like Clinic-N, Clinic-C was created during the 1996 regional pilot project. Yet, it has always received the highest number of MIS's healthcare demands when compared to other clinics, accounting for roughly half of them in the whole region. To respond to the high demand-pressure, the public organisation's high-level managers extended the opening time of the clinic, from $3 \mathrm{~h} /$ day and 3 days/week, to $7 \mathrm{~h} /$ day and 5 days/week. Differently from Clinic-N, however, this extension did not come with a commensurate increase in organisational resources. Instead, since the early 2010s the high-level management reduced the personnel working at the clinic to counter the high financial unbalance of the public health organisation, which was the one targeted the most by the region's deficit reduction plan due to its serious financial situation.

In such context, the regional model and MIS' entitlements have been increasingly questioned by the management. It defined the provision of free-of-charge healthcare for MIS as "a problem" and the clinic as a "black hole swallowing up the organisation's resources" (interview, high-level manager, Clinic-C). Similarly, it increasingly assumed a critical stance towards the CCG and its decisions, describing its defenders as "not having the slightest idea of what happens on the ground" (fieldnotes, high-level manager, Clinic-C). Street-level workers were thus required to "selectively verify each access to avoid abuses" (fieldnotes, high-level manager, Clinic-C). Therefore, while still complying with the regional law in terms of formal structure, the high-level management redefined the mission of the clinic and its workers, from providing information and healthcare for MIS to tightening controls in order to "save the SSN from abuses" (fieldnotes, intercultural mediator, Clinic-C).

High-level priority towards cost reduction affected not only resource allocation to the clinic, resulting in a dramatic work overload of street-level workers, but also reoriented the latter's' expectations about their role and professional responsibility. As argued by a CCG member who was previously a Clinic-C's worker,

Professional autonomy has completely disappeared there. Because if you, as doctor, must reduce health prescriptions, otherwise high-level managers will punish you...

\footnotetext{
${ }^{3}$ This strategy was often adopted in relation to uninsured EU citizens who were living in Italy without complying with the requirements established by Directive 38/2004/EC.
} 
if, when you do not know what to do, you follow their [managers] indications ... then, you saw what will happen, it becomes a police station (interview, CCG-3).

Indeed, front-line workers at the Clinic- $\mathrm{C}$ frequently used their discretion to exclude MIS from public healthcare. They frequently described MIS as "fraudsters", "opportunistic", "not contributing to health expenditure", or "medical tourists" (fieldnotes, Clinic-C), thus "delegitimating patients" to manage potential cognitive dissonance between their ideal job and actual practices (Lipsky 1980[2010]; Brodkin 2011b). In so doing, they ascribed negative characteristics to MIS, whose condition of irregularity was described as a rational choice, voluntarily sought and perpetuated to access free-of-charge healthcare. Differently from the case of Clinic-N, these workers constructed MIS as "agents of illegality", thereby legitimating healthcare exclusion on moral-economic grounds. For instance, during the intake procedure, common decisions included refusing to register a person before a 90-day period of irregularity (rather than at the moment her/his stay permit expires), which can be quite difficult to assess if the person does not have an expired visa; or asking a person for additional papers than the ones required by law, contradicting the possibility granted by the national framework to register MIS into the system even in the absence of identity documents. At the medical room, doctors often refused to grant co-payment exemptions to MIS on the basis of moral judgements or economic suppositions, regardless of the person' self-declaration of lacking sufficient resources (as the law affirms). As contended by a doctor,

These people have more money than me. I mean, they are not poor. Just look at their golden necklaces and rings. Look at their IPhones! And so I do not attribute the co-payment exemption to them, they are not poor at all (interview, doctor-1, Clinic-C).

Importantly, such discretionary decisions were acknowledged as the "right" ones by the clinic's workers regardless of their contra legem nature. In Clinic- $\mathrm{C}$, gatekeeping had thus become a collective, organisational strategy.

\section{Clinic-S: ceremonial conformity and individual practices of in/exclusion}

Since the start of the 1996 pilot project, the opening of a clinic was opposed by the management of the third public health organisation involved in the research, as it did not share its aims, procedures and declared benefits. Likewise, it refused to participate in the CCG monthly meetings and adopt its procedural indications, defining the group as composed of "pseudo do-gooder bureaucrats who only teach MIS how to trick the system" (interview, administrative line-manager, Clinic-S). In 2008, however, the noncompliance was sanctioned by the region, which obliged the organisation to align with the regional law, otherwise it would have had to pay all costs related to MIS's healthcare sustained out of the standard regional procedure. Consequently, the organisation "ceremonially conformed" (Meyer and Rowan 1977) to the regional rules: it formally opened a clinic in its territory, yet it concretely downsized its scope and activities. 
Accordingly, at Clinic-S, high-level priorities - and the consequent resource allocation- highly differed between the administrative desk and the medical room. Resources were increased in the registration process: over time, additional workers have been employed and put under the direct supervision of the management, whose orientation towards the regional model was quite explicit: "We are not here to teach them how to trick and exploit our system" (fieldnotes, administrative line-manager, Clinic-S).

Being directly trained by the administrative line manager, administrative workers at Clinic-S always acted in conformity with her orientation, taking her prescriptions and procedural indications for granted. In explaining a decision to refuse access to a pregnant Turkish woman who did not have identity documents, an administrative worker explained me that "I know that the law states that, even without documents, the registration code should be issued. However, we have decided to ask for documents. You know, it is by hiding documents that they [MIS] trick the system!" (fieldnotes, administrative worker, Clinic-S).

In contrast, few resources were allocated to the medical phase, showing the managerial neglect of the health dimension of the service- or even its implicit opposition to it. The clinic's medical room was open only half an hour per day and lacked any medical furniture; no medical reports concerning MIS' health status were compiled and no intercultural mediators had been employed ("We use Google Translate", they told me); eight doctors were assigned to the clinic on a rotation mechanism (each doctor worked there twice a month), limiting the development of any "doctor-patient relation".

In the absence of any direct supervision or training from the management, doctors at Clinic-S performed their role in relation to their individual views and positioning, resulting in a high degree of intra-organisational variation in medical practices. On the one hand, two doctors argued against providing healthcare for MIS. They referred to MIS's "illegal" and "opportunistic" behaviours to legitimate their exclusionary practices, resembling the narratives health workers relied on at Clinic-C. In a nurse's words,

These [migrants] arrive here, and they stay here for like ten years. They are always the same, and probably they work, too. They are not clandestine! It is only that it is easier to come here, to receive free healthcare and not pay taxes. And all of this can be blamed on Italian permissiveness!

Not acknowledging MIS as "patients", these doctors often asked migrants about their health needs in the hallway of the structure or at the doorway, without respecting their privacy or the principle of professional confidentiality. Likewise, they often verified MIS' identity documents. Sometimes, they openly and formally contested the registration of a person into the system, requiring explanations for that decision from administrative workers. As a doctor stated,

I think that if I know that you are not employed, I come to your home and I ask you: 'How do you eat? By paying nothing? I mean, you either regularize yourself or you go away!. And maybe we, as doctors, should report them to the police. (interview, doctor-1, Clinic-S) 
On the other hand, three doctors claimed for the provision of health services for MIS, mobilising principles of medical-humanitarianism ("I am a doctor, and when I encounter a sick person who needs care, I'll take care of her" - fieldnotes, doctor-3, Clinic-S), human rights ("I treat you like a person and, as a person, you are a human being holding rights" - interview, doctor-4, Clinic-S), or public health ("Although they are defined as 'temporarily-present foreigners', most of them have lived here for more than ten years. They live here, and we must provide healthcare to them" - interview, doctor-5, Clinic-S). Confronted with the indifference of high-level managers, these professionals often met patients outside of their working hours and the clinic's structure, or helped MIS find alternative ways to access healthcare, referring them to civil society organisations or health professionals that they trusted. Sometimes, they personally questioned administrative refusals of patients they believed to be in need of care.

In between of these positioning, three professionals argued against improving the activities of the clinic and providing a more structured and continuous service, justifying it with the small number of MIS requiring healthcare access and their general healthy status. By neglecting migrants' presence and needs, these doctors' routines usually consisted of prescribing basic medicines or examinations by specialists, without asking the person about the reasons behind that request or getting concerned about any eligibility problems MIS encountered. By minimising their individual commitment towards "cases", they shifted any responsibility for MIS' healthcare access: up to national and Regional laws ("I'm only an executant of the law" [interview, doctor-6, Clinic-S]); out, by trivialising their encounters with MIS (as "mere moments of prescriptions of medications and referrals to professionals providing secondary care" [interview, doctor-7, Clinic-S]), or down to migrants and their condition of illegality ("At the end, we are talking about clandestine people" [interview, doctor-8, Clinic-S]).

Therefore, at Clinic-S discretionary decisions were highly heterogeneous, differently from the two previous cases-where discretionary practices assumed the form of organisational strategies of healthcare inclusion (Clinic-N) or exclusion (Clinic-C) as they were supported by the management and shared by street-level workers. While at the registration desk of Clinic-S, workers' practices (of exclusion) showed a high level of coherence, in line with managers' critical stance towards the regional healthcare model, at the medical room discretionary practices (of in/exclusion) fell under workers' individual responsibility.

\section{Conclusions. Street-level practices, organisations, institutions: cutting across levels}

Drawing on a comparative ethnographic case study of three public health organisations in the Northern Italian region of Piemonte, this article investigated how organisations mediate the access to healthcare for MIS. By linking the street-level bureaucracy literature with the neo-institutionalist perspective in organisational analysis, the paper suggests that, in contexts characterised by tensions at the institutional level, high-level managers' priorities and framings of a policy issue, the ways they respond to decisionmakers' goals and policies over time, and allocate organisational resources for implementing them, play a key role in orienting the practices of street-level workers in their daily encounters with MIS, which ultimately determine migrants' inclusion into - or exclusion from - public healthcare. 
As the findings suggest, in fact, street-level workers often confronted the legal prescriptions regulating healthcare access for MIS. However, the types of practices they adopted, the motivations behind them and, consequently, their practical consequences for MIS varied across and within the three public health organisations. Exclusionary gatekeeping appeared more prevalent at Clinic-C and Clinic-S, while discretionary practices of healthcare inclusion seemed more institutionalised at Clinic-N. These dynamics suggest that while workers' individual predispositions played a role in the adoption of discretionary practices, as individual-level explanations of discretion contend (Lipsky 1980), action patterns of healthcare in/exclusion towards MIS were shaped by the interplay of institutional and organisational factors in the field.

\section{Tensions at the institutional level}

Institutions shape street-level practices and issue framings, constraining actors' perceptions and actions (Thornton and Ocasio 2008; Peters 2019). They give meaning to and orient the patterns of practices that are assumed to be appropriate and legitimate within a field. As the findings confirm, the definition of MIS' healthcare access in the 1998 Law and the regional model of dedicated clinics for MIS in Piemonte were the result of the mobilisation of individual actors and professional networks that engaged in advocating for the provision of healthcare to MIS. While doing so, they established a medical-humanitarian - rather than a right-based - frame of the issue (Ticktin 2006). Accordingly, healthcare access for MIS has not been grounded on their "right to" (healthcare), as no reference is made to concepts of rights or entitlement in the 1998 Law. Instead, it depends on the recognition of a "need of" (urgent and essential care) from healthcare actors.

However, when the institutional context became contradictory, as a result of the progressive "layering" of cost-containment and migration-control goals on top of the 1998 Law, the legitimacy of the regional healthcare model, its frames and policy tools became increasingly questioned. In that context, the positioning of regional decisionmakers and public health organisations' managers increasingly polarised between a medical-humanitarian frame on the one hand - with some actors sustaining healthcare provision for MIS and the regional model, like in the case of Clinic-N - and a controloriented frame on the other - with other organisations calling for stricter controls against "undeserving migrants", as the Clinic- $\mathrm{C}$ and Clinic-S indicate.

As street-level workers are exposed to the institutional logics operating in a field through their membership in organisations that are part of it (Garrow and Grusky 2013), the role of organisations in (re-)orienting practices becomes central.

\section{Organisational level: managers' positioning (across organisations) and allocation of resources (within organisations)}

Although the three public health organisations operated in the same institutional context and were subject to the same rules and procedures, they implemented the regional policy at various degrees, depending on whether the management "substantially" or "ceremonially" complied (Meyer and Rowan 1977) with the regional model's established frames and tools. 
In the case of Clinic- $\mathrm{N}$, the public health organisation's management participated in, substantially complied with, and defended over time the regional model and its underlying principles. Hence, it exercised its autonomy in order to improve the service over time and used its margins for discretion when confronted with MIS in high need of expensive treatments. On the contrary, at Clinic- $\mathrm{C}$, the organisation's management moved from substantial to ceremonial conformity due to changing (fiscal) priorities, whereas at Clinic-S the management was forced to conform to the regional model in spite of its opposition to it. In these two cases, the high-level management used its organisational autonomy to re-define the mission of the clinic. This opposition became explicit during the "institutional crisis", when these managers felt legitimated to openly question the regional healthcare model. Through their sustained exclusionary gatekeeping discourses and practices, they replicated and produced a hostile environment against those MIS they interpreted as not deserving access to public healthcare.

As the comparative analysis of the three clinics suggests, managers' priorities significantly shaped street-level practices of in/exclusion on the ground. They had direct and indirect effects on the interpretations that workers developed about "what counts" in their organisation and the scope of their room for manoeuvre (Brodkin 2011a). Specifically, where health workers were not confronted with resource constraints andwere supported by the management in exercising the clinic's mission, as in the case of Clinic-N, they were enabled to adopt and adapt rules in relation to patients' needs. In this case, the high-level and line management, as well as health workers shared a commitment to the idea of their work as providing healthcare to vulnerable migrants. On the contrary, where health workers faced high-level pressures towards gatekeeping (due to resource constraints in Clinic- $\mathrm{C}$, or management's substantive opposition to the regional model in Clinic-S), they often used their margins for manoeuvre to adopt practices of healthcare exclusion towards MIS. In so doing, they re-framed MIS' undeservingness of healthcare, shifting the responsibility for exclusion to "medical tourists" and "illegal migrants". Nevertheless, while in the case of Clinic-C the management and health workers converged towards restrictive practices, in the case of Clinic-S variation emerged between occupations (administrative compliance vs. health professional heterogeneity).

These findings confirm that professional status may influence the extent of discretion that occupational groups exercise. However, they also challenge the argument that professionalism - characterised by an ideology that focuses on service user wellbeing (Evans 2011, p. 371), particularly in the healthcare domain - is consistently associated with a commitment to the "Hippocratic Oath". As part of their role, doctors are also responsible for avoiding unnecessary use of scarce healthcare resources. However, costcommitment - in contexts characterised by managerial orientation towards gatekeeping, and in the absence of sanctions for unlawful exclusion - may turn into discretionary exclusion of the ones interpreted to not deserve public healthcare.

Although the focus on a single Italian region may limit the generalizability of the findings, they converge with previous research in Europe (e.g. Larchanché (2012) on France; Grit et al. (2012) comparing the UK and the Netherlands) and beyond (e.g. Portes et al. (2009) on the US, Vanthuyne et al. (2013) on Canada). Moreover, the comparison of similar organisations in charge of implementing the same policy in the same organisational field was fundamental to bring to light the specific role of organisational dynamics and 
factors in orienting - and leading to variation in - street-level practices. In context characterised by significant tensions at the institutional level, street-level workers may take on different stances towards MIS and their healthcare entitlements. In this macro-micro interaction, however, organisations matter. High-level managers mediate how street-level workers perceive problems and the solution they imagine to deal with them, (re-)defining "who get what and how" on the front-line of healthcare systems.

\section{Abbreviations}

CCG: Clinics' Coordination Group; MIS: Migrants with irregular status; SIMM: Società Italiana di Medicina delle Migrazioni (Italian Society of Migration and Medicine); SSN: Sistema Sanitario Nazionale (National Healthcare System)

\section{Acknowledgements}

The author acknowledges support of the publication fee by Erasmus University and the CSIC Open Access Publication Support Initiative through its Unit of Information Resources for Research (URICI).

\section{Author's contributions}

The author(s) read and approved the final manuscript.

\section{Authors' information}

R.P. holds a PhD in Political Sociology from the University of Torino. She is postdoctoral fellow at the Institute of Public Goods and Policies of the Spanish National Research Council (CSIC-IPP), where she conducts her research on the welfare-mobility nexus from a comparative and multi-level perspective, and the politics of health-related deservingness in contemporary Europe.

\section{Funding}

Not applicable.

\section{Availability of data and materials}

The data are not publicly available as they contain information that could compromise research participant consent.

\section{Competing interests}

The author declares that she has no competing interests.

Received: 23 May 2020 Accepted: 27 January 2021

Published online: 27 April 2021

\section{References}

Alink, F., Boin, A., \& T'Hart, P. (2001). Institutional crises and reforms in policy sectors: The case of asylum policy in Europe. Journal of European Public Policy, 8(2), 286-306. https://doi.org/10.1080/13501760151146487.

Battilana, J., Leca, B., \& Boxenbaum, E. (2009). How actors change institutions: Toward a theory of institutional entrepreneurship. The Academy of Management Annuals, 3(1), 65-107. https://doi.org/10.1080/19416520903053598.

Bierschenk, T. (2014). Sedimentation, fragmentation and normative double-binds in (west) African public services. In T. Bierschenk, \& J.-P. O. de Sardan (Eds.), States at work. Dynamics of African bureaucracies (pp. 221-245). Leiden: Brill.

Boswell, C. (2007). Theorizing migration policy: Is there a third way? International Migration Review, 41(1), 75-100. https://doi. org/10.1111/j.1747-7379.2007.00057.x.

Brodkin, E. Z. (2011a). Putting street-level organizations first: New directions for social policy and management research. Journal of Public Administration Research and Theory, 21(s2), i199-i201. https://doi.org/10.1093/jopart/muq094.

Brodkin, E. Z. (2011b). Policy work: Street-level organizations under new managerialism. Journal of Public Administration Research and Theory, 21(s2), i253-i277. https://doi.org/10.1093/jopart/muq093.

Brodkin, E. Z. (2012). Reflections on street-level bureaucracy: Past, present, and future. Public Administration Review, 72(6), 940949. https://doi.org/10.1111/j.1540-6210.2012.02657.x

Chauvin, S., \& Garcés-Mascareñas, B. (2014). Becoming less illegal: Deservingness frames and undocumented migrant incorporation. Sociology Compass, 8(4), 422-432. https://doi.org/10.1111/soc4.12145.

Dauvrin, M., Lorant, V., Sandhu, S., Devillé, W., Dia, H., Dias, S., et al. (2012). Healthcare for irregular migrants: Pragmatism across Europe. A qualitative study. BMC Research Notes, 5, 99. https://doi.org/10.1186/1756-0500-5-99.

de Belvis, A. G., Ferrè, F., Specchia, M. L., Valerio, L., Fattore, G., \& Ricciardi, W. (2012). The financial crisis in Italy: Implications for the healthcare sector. Health Policy, 106(1), 10-16. https://doi.org/10.1016/j.healthpol.2012.04.003.

DiMaggio, P. J., \& Powell, W. W. (1983). The iron cage revisited: Institutional isomorphism and collective rationality in organizational fields. American Sociological Review, 48(2), 147-160. https://www.jstor.org/stable/2095101.

Ellis, K. (2011). Street-level bureaucracy revisited: The changing face of frontline discretion in adult social care in England. Social Policy and Administration, 45(3), 221-244. https://doi.org/10.1111/j.1467-9515.2011.00766.x.

Evans, T. (2011). Professionals, managers and discretion: Critiquing street-level bureaucracy. British Journal of Social Work, 41, 368-386. https://doi.org/10.1093/bjsw/bcq074.

Fernández-Kelly, P. (2012). Rethinking the deserving body: Altruism, markets, and political action in health care provision. Ethnic and Racial Studies, 35(1), 56-71. https://doi.org/10.1080/01419870.2011.594166.

Garcés-Mascareñas, B., \& Penninx, R. (2016). Integration processes and policies in Europe. Contexts, levels and actors. IMISCOE research series. Springer Open. 
Garrow, E. E., \& Grusky, O. (2013). Institutional logic and street-level discretion: The case of HIV test counseling. Journal of Public Administration Research and Theory, 23(1), 103-131. https://doi.org/10.1093/jopart/mus009.

Geraci, S., \& Bodini, C. (2011). Network of networks for immigrants' health. Salute e Società, X(2), 148-161. https://doi.org/10. 3280/SES2011-002ENG010.

Grit, K., den Otter, J. J., \& Spreij, A. (2012). Access to health care for undocumented migrants: A comparative policy analysis of England and the Netherlands. Journal of Health Politics, Policy and Law, 37(1), 37-67. https://doi.org/10.1215/036168781496011.

Hupe, P. (2019). Research handbook on street-level bureaucracy. The ground floor of government in context. Cheltenham: Edward Elgar Publishing.

Larchanché, S. (2012). Intangible obstacles: Health implications of stigmatization, structural violence, and fear among undocumented immigrants in France. Social Science \& Medicine, 74(6), 858-863. https://doi.org/10.1016/j.socscimed.2011. 08.016 .

Lawrence, T. B., \& Suddaby, R. (2006). Institutions and institutional work. In S. R. Clegg, C. Hardy, T. B. Lawrence, \& W. R. Nord (Eds.), Sage handbook of organization studies (2nd ed., pp. 215-254). London: SAGE Publishing.

Lipsky, M. (1980[2010]). Street-level bureaucracy. Dilemmas of the individual in public services [updated edition]. New York: Russell Sage Foundation.

Mahoney, J., \& Thelen, K. (2010). A theory of gradual institutional change. In J. Mahoney, \& K. Thelen (Eds.), Explaining institutional change. Ambiguity, agency, and power (pp. 1-37). Cambridge: Cambridge University Press.

Marrow, H. B. (2012). The power of local autonomy: Expanding healthcare to unauthorized immigrants in San Francisco. Ethnic and Racial Studies, 35(1), 72-87. https://doi.org/10.1080/01419870.2011.594168.

Maynard-Moody, S., \& Portillo, S. (2010). Street-level bureaucracy theory. In R. F. Durant (Ed.), The Oxford handbook of American bureaucracy (pp. 252-277). Oxford: Oxford University Press.

Meyer, J. W., \& Rowan, B. (1977). Institutionalized organizations: Formal structure as myth andceremony. American Journal of Sociology, 83(2), 340-363. https://www.jstor.org/stable/2778293.

Olivani, P., \& Panizzut, D. (2019). Attuale legislazione sanitaria italiana per gli immigrati irregolari e attuale fruibilità di tale legislazione a livello regionale. Rapporto 2019. Milano: NAGA. https://www.simmweb.it/attachments/article/973/Report_ LEGIS_Naga_2019.pdf.

Pasini, N., \& Merotta, V. (2016). The health of migrants. In V. Cesareo (Ed.), The twenty-first Italian report on migrations 2015 (pp. 41-47). Milano: McGraw-Hill Education.

Peters, B. G. (2019). Institutional theory in political science: The new institutionalism (4th ed.). Chaltenham: Edward Elgar Publishing.

Portes, A., Light, D., \& Fernández-Kelly, P. (2009). The U.S. health system and immigration: An institutional interpretation. Sociological Forum, 24(3), 487-514. https://doi.org/10.1111/j.1573-7861.2009.01117.x.

Powell, W. W., \& DiMaggio, P. J. (1991). The new institutionalism in organizational analysis. Chicago: The University of Chicago Press.

Riccucci, N. M., Meyers, M. K., Lurie, I., \& Han, J. S. (2004). The implementation of welfare reform policy: The role of public managers in front-line practices. Public Administration Review, 64, 438-448. https://doi.org/10.1111/j.1540-6210.2004.00390. $\mathrm{x}$.

Rice, D. (2012). Street-level bureaucrats and the welfare state: Toward a micro-institutionalist theory of policy implementation. Administration \& Society, 45(9), 1038-1062. https://doi.org/10.1177/0095399712451895.

Thelen, T., Vetters, L., \& von Benda-Beckmann, K. (2014). Introduction to Stategraphy. Toward a relational anthropology of the state. Social Analysis, 58(3), 1-19. https://doi.org/10.3167/sa.2014.580302.

Thornton, P. H., \& Ocasio, W. (2008). Institutional logics. In R. Greenwood, C. Oliver, R. Suddaby, \& K. Sahlin-Andersson (Eds.), The SAGE handbook of organizational institutionalism (pp. 99-129). London: SAGE Publishers.

Ticktin, M. (2006). Where ethics and politics meet: The violence of humanitarianism in France. American Ethnologist, 33(1), 3349. https://www.jstor.org/stable/3805315.

van der Leun, J. (2006). Excluding illegal migrants in the Netherlands: Between national policies and local implementation. West European Politics, 29(2), 310-326. https://doi.org/10.1080/01402380500512650.

Vanthuyne, K., Meloni, F., Ruiz-Casares, M., Rousseau, C., \& Ricard-Guayc, A. (2013). Health workers' perceptions of access to care for children and pregnant women with precarious immigration status: Health as a right or a privilege? Social Science \& Medicine, 93, 78-85. https://doi.org/10.1016/j.socscimed.2013.06.008.

Zincone, G. (1998). Illegality, enlightenment and ambiguity: A hot Italian recipe. South European Society and Politics, 3(3), 4582. https://doi.org/10.1080/13608740308539547.

Zincone, G., Penninx, R., \& Borkert, M. (2011). Migration policymaking in Europe. The dynamics of actors and contexts in past and present, IMISCOE research. Amsterdam: Amsterdam University Press.

\section{Publisher's Note}

Springer Nature remains neutral with regard to jurisdictional claims in published maps and institutional affiliations. 